\title{
THE Rh ANTIGEN Cu
}

\section{R. R. RACE and RUTH SANGER \\ Medical Research Council Blood Group Research Unit, Lister Institute, London}

Received 3.i.5 I

The $R h$ antigens $c^{v}$ and $C^{u}$, allelomorphic to $C, c$ and $C^{w}$, were described by Race, Sanger and Lawler (1948a and $b$ ). The description of $C^{u}$ was notably incomplete; the donor could not be traced, and consequently the inheritance of the antigen could not at that time be demonstrated. Nevertheless, the sharp serological differences left no doubt that this new form of the $C$ antigen must be due to an allelomorphic gene. It was estimated that the gene frequency of $C^{u}$ is of the order of 0.2 per cent. in England. The antigen differed from the usual $C$ in that the red cells carrying it were agglutinated by only two out of the ix anti- $C$ sera with which they were tested.

The $C^{u}$ propositus has recently been traced and it has been possible to test the blood of his mother, the only relative available. By good fortune the mother not only has the antigen but has it in a combination in which it can be recognised, that is $C^{u} c$. The propositus is $O$ and his mother $A_{1}$, otherwise their blood groups are the same, namely, $C^{u} D_{e} / c d e, M s \mathcal{N} s, P+, L u(a-), K-, L e(a-)$ and $F y(a+)$.

The table shows the results of testing the blood of the propositus in r 947 and in $195^{\circ}$, and of his mother in $195^{\circ}$.

The two examples of $C^{u} c$ cells were tested against titrations of the antisera shown in the table. No definite quantitative differences were revealed, for when $C^{u}$ is agglutinated it usually scores as highly as $C$ : moreover, our strongest anti-C $\operatorname{serum~}(B a$.$) is amongst those$ which fail to agglutinate $C^{u} c$ cells.

The table also shows the reactions in albumin of two anti- $C$ and two anti- $C^{w}$ sera. These sera lacked incomplete anti- $D$ and therefore could be used without the $D$ reaction confusing the issue. Of these four sera, $M a$. was the only one to give a positive antiglobulin test with $C^{u} c$ and $C c$ cells ; $E d$. does not give a positive anti-globulin test with any $C$ cells though the reaction is quite powerful in albumin.

Absorption tests showed that the cells of the propositus were able to remove anti- $C$ from the serum $B a$. (which does not agglutinate $C^{u} c$ cells in saline) and from the sera $H i$. and $E d$. (which do agglutinate $C^{u} c$ cells in saline). In no case was the absorption quite as efficient as that brought about by $C c$ cells. It was only possible to test the absorptive power of the cells of the mother against one serum, $B a$. For some unexplained reason these cells were less efficient at removing anti- $C$ than were the cells of her son and only slightly more efficient than the $c D e / c d e$ control cells. 
R. R. RACE AND R. SANGER

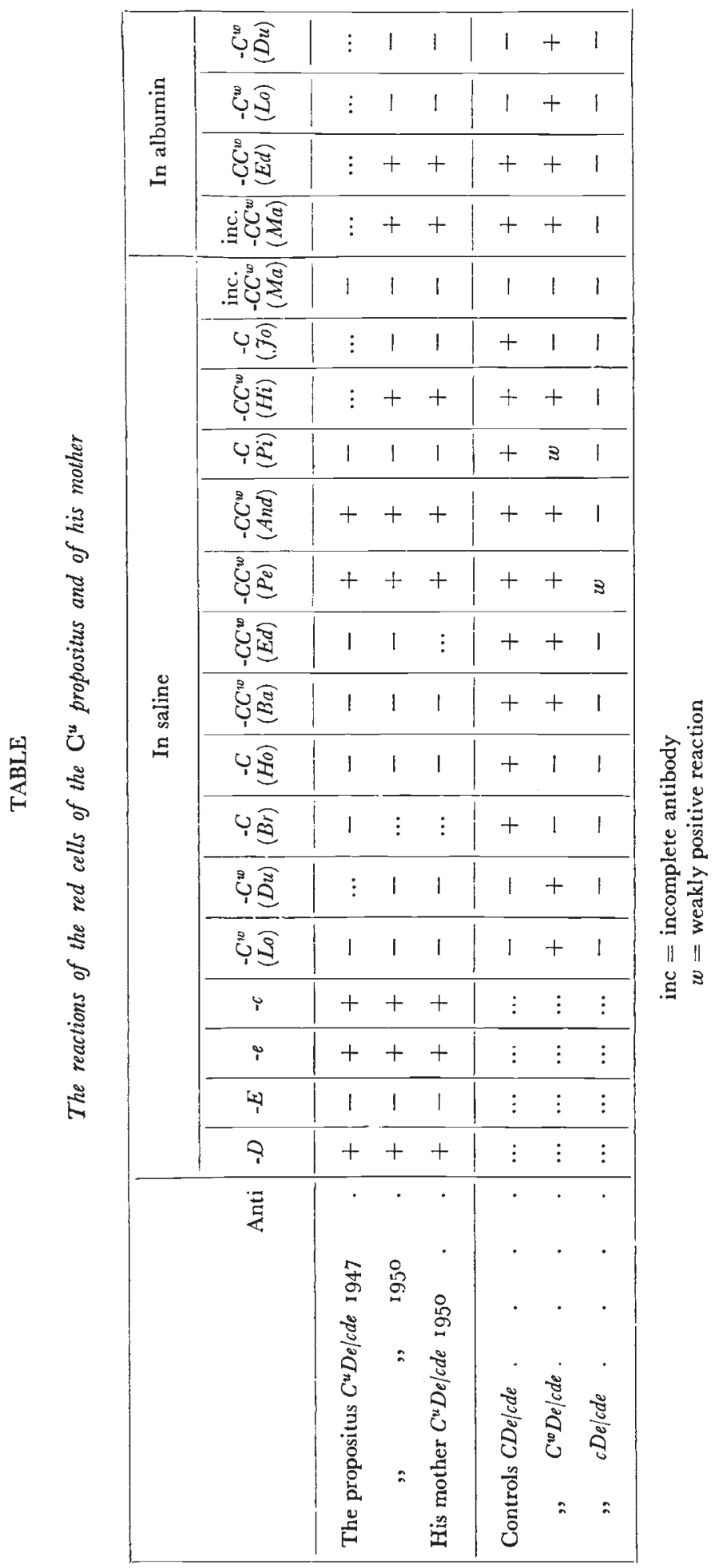


Another serological problem arose when it was found that the $B a$. serum which does not agglutinate $C^{u} D e / c d e$ cells in saline would do so after repeated absorption with $c D e / c d e$ cells ; this was not due to unmasking of anti- $D$, for $c D e / c d e$ cells were not agglutinated by the absorbed serum.

Unfortunately circumstances prevented either of these problems being pursued and this paper is therefore confined to the demonstration of the inheritance of the antigen $C^{u}$.

Acknowledgments.-We are greatly indebted to Dr W. Weiner, of the National Blood Transfusion Service, Birmingham, who traced the original $C^{u}$ donor and obtained samples of blood from him and his mother.

\section{REFERENCES}

RACE, R. R., SANGER, RUTH, AND LAWLER, SYLVIA D. 1948a. Rh genes allelomorphic to $C$. Nature, Lond., $16 r, 316$.

RACE, R. R., SANGER, RUTH, AND LAWLER, SYLVIA D. 1948b. Allelomorphs of the $R h$ gene $C$. Heredity, 2, 237-250. 